\title{
Proline partially overcomes excess molybdenum toxicity in cabbage seedlings grown in vitro
}

\author{
J. Kumchai ${ }^{1}$, J.-Z. Huang' ${ }^{2}$ C.-Y. Lee ${ }^{2}$, F.-C. Chen ${ }^{2}$ and S.-W. Chin ${ }^{2}$ \\ ${ }^{1}$ Department of Tropical Agriculture and International Cooperation, \\ National Pingtung University of Science and Technology, Pingtung, Taiwan \\ ${ }^{2}$ Department of Plant Industry, \\ National Pingtung University of Science and Technology, Pingtung, Taiwan \\ Corresponding author: S.-W. Chin \\ E-mail: swchin@mail.npust.edu.tw
}

Genet. Mol. Res. 12 (4): 5589-5601 (2013)

Received November 5, 2012

Accepted February 5, 2013

Published November 18, 2013

DOI http://dx.doi.org/10.4238/2013.November.18.8

\begin{abstract}
In vitro grown cabbage (Brassica oleracea var. capitata) seedlings exposed to excess molybdenum (Mo) ions exhibited severely reduced plant growth at the cotyledonary stage. Adding $80 \mathrm{mM}$ proline (Pro) to the Mo-treated medium could help 50\% seedlings to overcome the toxicity and grow true leaves. Under excess Mo stress, seedlings accumulated blue/purple anthocyanin in their cotyledons and hypocotyls. The anthocyanin content under Mo with $40 \mathrm{mM}$ Pro was 4-fold higher than the control medium, MS with $40 \mathrm{mM}$ Pro. The presence of Pro in the excess-Mo condition reduced chlorophyll $a$, whereas the chlorophyll $b$ content was much higher than the control media of MS with and without Pro. Moreover, supplementing various concentrations of Pro into the Mo-stressed condition promoted the seedlings with higher antioxidant enzyme activities of superoxide dismutase, ascorbate peroxidate, and catalase. In addition, genes in the anthocyanin biosynthesis and accumulation pathways, phenylalanine ammonia lyase $(P A L)$, chalcone synthase $(\mathrm{CHS})$, flavonone 3-hydroxylase $(F 3 H)$, leucoanthocyanidin dioxygenase $(L D O X)$, and glutathione-S-transferase $(G S T)$, were all upregulated. Our study indicated that, under excess Mo stress, the
\end{abstract}


antioxidant activity of cabbage seedlings was induced in an attempt to protect plants from the Mo-induced toxicity and exacerbated growth. Pro, on the other hand, functioned in producing higher antioxidant enzyme activity to partially help recover plant growth.

Key words: Anthocyanin; Chlorophyll; Growth inhibition; Antioxidant enzyme activity; Gene upregulation

\section{INTRODUCTION}

Molybdate $\left(\mathrm{Na}_{2} \mathrm{MoO}_{4} \cdot \mathrm{H}_{2} \mathrm{O}\right)$ is an essential element required for the growth of plants during their life cycle (Kaiser et al., 2005). Mo is distributed throughout the environment and in the soil. It has been used widely for industrial stainless steel, mining, cast iron, fertilizer manufacture, and agricultural activities (Mendel, 2005). Unlike cationic metals, the availability of Mo to higher plant species generally increases with a higher soil pH (Smith et al., 1997). Although higher plants require the balance of these essential elements by uptake from the soil, absorption of a higher Mo amount may impose toxicity symptoms, and at the same time also induce antioxidant enzyme activity and increase of anthocyanin accumulation in plant tissues to overcome the excess metal stress (Stroud et al., 2010). Excessive levels of heavy metals, such as copper, molybdenum, selenium, and zinc, in plant tissues can lead to stress conditions by inducing the formation of harmful reactive oxygen species (ROS) (Schützendübel and Polle, 2002). This consists of the exaggerated generation of free radicals (hydroxyl radical, $\mathrm{OH}^{-}$; phenoxy radicals, $\mathrm{RO}^{-}$; peroxy radicals, $\mathrm{ROO}^{-}$) and other $\mathrm{ROS}$ (superoxide radical anion, $\mathrm{O}_{2}^{-}$; singlet oxygen, ${ }^{1} \mathrm{O}_{2}$; hydrogen peroxide, $\mathrm{H}_{2} \mathrm{O}_{2}$ ) (Posmyk et al., 2009). The generation of ROS is considered to be a primary event under a variety of stress conditions (Baryla et al., 2000). In order to control the level of ROS and to protect cells under stress conditions, plant tissues are stimulated to produce several enzymes for scavenging ROS, including superoxide dismutase (SOD), ascorbate peroxidase (APX), and catalase (CAT), as well as a network of low molecular weight antioxidants (ascorbate, glutathione, phenolic compounds, tocopherol, and carotenoids) (Posmyk et al., 2009). SOD is the main antioxidant enzyme, catalyzing a disproportionate amount of superoxide anion $\left(\mathrm{O}_{2}^{-}\right)$to $\mathrm{H}_{2} \mathrm{O}_{2}$ (Bowler et al., 1992), whereas APX and CAT are the main enzymatic scavengers of $\mathrm{H}_{2} \mathrm{O}_{2}$ in plants and catalyze the reduction of $\mathrm{H}_{2} \mathrm{O}_{2}$ into water and molecular oxygen.

Proline (Pro), an amino acid, is essential for primary metabolism (Tan et al., 2011). Higher plants tolerant to water deficits and salinity stress usually accumulate higher levels of Pro to cope with the harsh environments (Dinakar et al., 2009). Nazarbeygi et al. (2011) reported that more Pro is produced in plant tissues encountering heavy metal stress to maintain the plant's ability to tolerate stress conditions. Rapid catabolism of Pro upon relief of stress may provide reducing equivalents that support mitochondrial oxidative phosphorylation and the generation of ATP for recovery from stress and repair of stress-induced damages (Hare et al., 1998). Moreover, it can protect enzymes by scavenging ROS (Gajewska and Skłodowska, 2005).

The aim of this study was to evaluate whether L-Pro could protect cabbage seedlings from Mo stress by activating enzyme activity and antioxidant accumulation in plant tissues, as well as to understand the regulation of anthocyanin biosynthesis genes under Mo stress. 


\section{MATERIAL AND METHODS}

\section{Plant growth conditions and parameter measurement}

The commercial cabbage (Brassica oleracea var. capitata) hybrid variety 'KY Cross' was used for all experiments. Seeds were surface-sterilized by use of $0.6 \%$ sodium hypochloride for $15 \mathrm{~min}$ and washed three times with sterile water before grown in MS medium (Murashige and Skoog, 1962) supplemented with $20 \mathrm{~g} / \mathrm{L}$ sucrose and $8 \mathrm{~g} / \mathrm{L}$ Sigma agar. Two days after seed germination, young seedlings were removed carefully from the agar medium and transplanted into both MS medium and MS with $10 \mathrm{mM}$ sodium molybdate. L-Pro at $0,20,40$, 60 , and $80 \mathrm{mM}$ was supplemented into these treatments. The in vitro cultures were kept at $25^{\circ}$ $\pm 2{ }^{\circ} \mathrm{C}$ under a $16 / 8 \mathrm{~h}$ photoperiod with a light intensity of 35 to $40 \mu \mathrm{mol} \cdot \mathrm{m}^{-2} \cdot \mathrm{s}^{-1}$ provided by cool-white fluorescent lamps (Starcoat ${ }^{\mathrm{TM}}$ F28W/T5/840,170 MA; Hungary). Four days after treatments with MS and/or Mo with and without Pro, seedlings were harvested and frozen with liquid nitrogen and stored at $-80^{\circ} \mathrm{C}$ until use. The lengths of the root, hypocotyls, and cotyledons, the cotyledon width, the percentage of seedlings with root hairs, and true leaves were recorded, respectively. The means of 15 seedlings for each treatment were collected and subjected to statistical analysis by the Fisher protected LSD test at $\mathrm{P} \leq 0.05$ and Student $t$-test analysis at $\mathrm{P}=0.05$ between MS and Mo with the same Pro levels.

\section{Cross-section of tissues}

Seedling hypocotyls and cotyledons were removed from the culture plate and crosssectioned with a surgical blade. Tissue sections were incubated in $0.5 \%$ polyethylene glycol and bubbles were expelled by a rotary vacuum pump (SV-3A No. 908) for 15 to $20 \mathrm{~min}$. The sectioned samples were then examined under a light microscope (Olympus CX40) and images were recorded using an Olympus E420 digital camera.

\section{Determination of anthyocyanins and chlorophylls}

The chlorophyll (Chl) content was determined according to Hartmut and Buschmann (2001). The chlorophyll was extracted from cotyledons by using pure methanol. The chlorophyll $a$ and $b$ contents were determined by a spectrophotometer (Hitachi U-2900 UV-Vis Double Beam System) with adsorption values at 665.2, 652.4, and $470 \mathrm{~nm}$. The concentration for $\mathrm{Chl} a(\mathrm{Ca})$, Chl $b(\mathrm{Cb})$, and total $\mathrm{Chl}(\mathrm{Ca}+b)$ was calculated with the following equations given for methanol as pure solvent, where the pigment concentrations are given in $\mu \mathrm{g} / \mathrm{mL}$ extract solution:

$$
\begin{aligned}
C a(\mu \mathrm{g} / \mathrm{mL}) & =16.72 \mathrm{~A}_{665.2}-9.16 \mathrm{~A}_{652.4} \\
C b(\mu \mathrm{g} / \mathrm{mL}) & =34.09 \mathrm{~A}_{652.4}-15.28 \mathrm{~A}_{665.2} \\
C a+b(\mu \mathrm{g} / \mathrm{mL}) & =24.93 \mathrm{~A}_{652.4}-1.44 \mathrm{~A}_{665.2}
\end{aligned}
$$

For anthocyanin determination, 0.12 to $0.2 \mathrm{~g}$ cotyledons was extracted in $1 \% \mathrm{HCl}$ in methanol, and the crude extracted was left overnight at $4^{\circ} \mathrm{C}$. Chloroform $(500 \mu \mathrm{L})$ was then added and the mixture was centrifuged at $13,000 \mathrm{rpm}$ (Centrifuge $5415 \mathrm{R}$ ) at $4^{\circ} \mathrm{C}$ for $5 \mathrm{~min}$. 
The supernatant was used for anthocyanin measurement by a spectrophotometer (Hitachi U-2900 UV-Vis Double Beam System) at 510 and $700 \mathrm{~nm}$ after the differential $\mathrm{pH}$ method (Giusti and Wrolstad, 2001). The calculation followed the monomeric anthocyanin pigment concentration in the original sample using the absorbance of the diluted sample as follows: $\mathrm{A}=\left(\mathrm{A}_{510}-\mathrm{A}_{700}\right)_{\mathrm{pH} 1.0}-\left(\mathrm{A}_{510}-\mathrm{A}_{700}\right)_{\mathrm{pH} 4.5}$.

$$
\text { Total anthocyanin content }(\mathrm{mg} / \mathrm{L})=(\mathrm{A} \times \mathrm{MW} \times \mathrm{DF} \times 1000) /(\varepsilon \times 1)
$$

where $M W$ is the molecular weight of cyanidin-3-glucoside (449.2 $\mathrm{g} / \mathrm{mol}), D F$ is the dilution factor, and $\varepsilon$ is the molar absorptivity $\left(26,900 \mathrm{~L} \cdot \mathrm{mol}^{-1} \cdot \mathrm{cm}^{-1}\right)$. The final anthocyanin content was converted to $\mathrm{mg} / \mathrm{g}$ FW.

\section{Antioxidant enzyme extraction and activity assay}

The cotyledons were extracted with $50 \mathrm{mM}$ sodium phosphate buffer, $\mathrm{pH}$ 7.0, and the solution was centrifuged at $13,000 \mathrm{rpm}$ for $20 \mathrm{~min}$ at $4^{\circ} \mathrm{C}$. The supernatant was analyzed for total protein and enzyme activity according to the methods adapted from Gajewska and Skłodowska (2005) and Posmyk et al. (2009). The protein content was determined according to Bradford (1976), where the mixture of $1 \mu \mathrm{L}$ crude extraction with $299 \mu \mathrm{L}$ Protein Assay Dye Reagent Concentrate (Bio-Rad Protein Assay) and $700 \mu \mathrm{L}$ distilled water was incubated at room temperature for $5 \mathrm{~min}$. The reaction was measured spectrophotometrically at $595 \mathrm{~nm}$.

SOD activity was measured according to the methods of Masayasu and Yoshikawa (1979) and Paoletti et al. (1986). The reaction mixture consisted of $0.055 \mu \mathrm{M}$ nitro blue tetrazolium (NBT), $50 \mathrm{mM}$ Tris-HCl, $0.1 \mathrm{mM}$ ethylenediaminetetraacetic acid (EDTA), 16 $\mu \mathrm{M}$ pyrogallol, $1.4 \%$ Triton $\mathrm{X}-100,0.778 \mathrm{~mL}$ distilled water, and $200 \mu \mathrm{L}$ enzyme extract in a final total volume of $1 \mathrm{~mL}$. The mixtures were reacted at $37^{\circ} \mathrm{C}$ for $10 \mathrm{~min}$ and then the absorption was measured spectophometrically at $540 \mathrm{~nm}$. One unit of SOD activity was defined as the enzyme activity that caused the inhibition of NBT by $50 \%(\mathrm{w} / \mathrm{v})$. The activity was expressed as SOD unit $\cdot \mathrm{mg}$ protein ${ }^{-1} \cdot \mathrm{min}^{-1}$.

For determination of APX activity, the reaction mixture contained $150 \mu \mathrm{M}$ sodium phosphate buffer, $\mathrm{pH} 7.0,1.5 \mu \mathrm{M}$ ascorbate, $6 \mathrm{mM} \mathrm{H}_{2} \mathrm{O}_{2}, 0.75 \mathrm{mM}$ EDTA, and $50 \mu \mathrm{L}$ enzyme in a total volume of $1.5 \mathrm{~mL}$. The reaction was carried out for $1 \mathrm{~min}$ at room temperature, and the absorbance was analyzed at $290 \mathrm{~nm}$. The enzyme activity was expressed as $\mu$ mole ascorbate oxidized $\cdot \mathrm{mg}$ protein ${ }^{-1} \cdot \mathrm{min}^{-1}$, according to the method of Nakano and Asada (1981).

CAT activity was measured in a mixture containing $0.5 \mathrm{M}$ sodium phosphate buffer, $\mathrm{pH} 7.0,10 \mathrm{mM} \mathrm{H}_{2} \mathrm{O}_{2}$, and $100 \mu \mathrm{L}$ enzyme extract. The final volume was $1.6 \mathrm{~mL}$. The reaction was carried out for $1 \mathrm{~min}$ and the absorbance was measured at $240 \mathrm{~nm}$. The enzyme activity was expressed as $\mu$ mole $\mathrm{H}_{2} \mathrm{O}_{2}$ decomposed $\cdot \mathrm{mg}$ protein ${ }^{-1} \cdot \mathrm{min}^{-1}$, according to the method of Kato and Shimizu (1985).

\section{Real-time reverse transcriptase-polymerase chain reaction (RT-PCR) analysis}

The total RNA was isolated from $0.2 \mathrm{~g}$ cotyledons according to manufacturer protocols (Invitrogen) by use of the TRIzol reagent. RNA precipitates were resuspended in diethylpyrocarbonate (DEPC)-treated sterile water and precipitated with $\mathrm{LiCl}$ (at a final 
concentration of $2 \mathrm{M}$ ). The supernatant was treated with RNase-free DNase I (Promega) at $37^{\circ} \mathrm{C}$ for 30 min to remove residual genomic DNA. Purified RNAs were quantified by spectrophotometry (U2000, Hitachi) and quality-checked by agarose gel electrophoresis. Total RNA $(5 \mu \mathrm{g})$ was treated with DNase I and used for first-strand cDNA synthesis by priming with oligo-d(T) ${ }_{15}$ and catalyzed with Superscript II Reverse Transcriptase (Invitrogen) at $42^{\circ} \mathrm{C}$ for $1.5 \mathrm{~h}$. Real-time PCR and data analysis were performed in the Applied Biosystems 7300 Real-Time PCR System with SYBR Green PCR Master Mix (Applied Biosystems) and the endogenous control for quantification was the Actin gene. The primers used were according to Yuan et al. (2009). Before running the real-time PCR, the primer efficiency of the target genes and housekeeping genes was evaluated by testing at 100, 200, and $300 \mathrm{nM}$. The primers are shown in Table 1 . The real-time PCR condition was $10 \mathrm{~min}$ at $95^{\circ} \mathrm{C}$, and 40 cycles of $15 \mathrm{~s}$ at $95^{\circ} \mathrm{C}$ and $1 \mathrm{~min}$ at $60^{\circ} \mathrm{C}$. Each sample was amplified in triplicate and all PCRs were performed on the Applied Biosystems 7300 Real-Time PCR System. With the housekeeping gene Actin, the relative amount of the gene transcript was presented as $2^{-\Delta C T}$, according to the $\Delta \mathrm{C}_{\mathrm{T}}$ method described in the real-time PCR Applications Guide (Applied Biosystems).

\begin{tabular}{|c|c|c|c|}
\hline Genes & Primer sequence $\left(5^{\prime} \rightarrow 3^{\prime}\right)$ & Primer concentrations (nM) & Accession No. \\
\hline \multirow[t]{2}{*}{$\overline{\text { ACTIN }}$} & F: CTGTGACAATGGTACCGGAATG & 100 & AF044573 \\
\hline & R: ACAGCCCTGGGAGCATCA & 100 & \\
\hline \multirow{2}{*}{ PAL } & F: CAGAGCAACACAACCAAGACGTGAA & 300 & BH716217 \\
\hline & R: TCTCCTCCAAGTGTCGTAGATCGATG & 100 & \\
\hline \multirow[t]{2}{*}{ CHS } & F: GCGCATGTGCGACAAGTCGAC & 200 & EF408921 \\
\hline & R: CCTGTCGAGCGTCGAGAGAAGGA & 200 & \\
\hline \multirow[t]{2}{*}{ F3H } & F: GTCATCTTCAGGGAGAGTCTGTTCA & 200 & DQ288239 \\
\hline & R: TCGCTGTACTCCTCCGTCACTT & 200 & \\
\hline \multirow{2}{*}{ LDOX } & F: GTGGACAGCTTGAGTGGGAAGATTAC & 300 & AY228485 \\
\hline & R: GTACTCACTCGTAGCTTCAATGTAATCAG & 100 & \\
\hline \multirow[t]{2}{*}{ GST } & F: CTTGTAGCCATTTGGTCAA & 300 & BH738469 \\
\hline & R: GAGACTTGCCCAAAAGGTTCGT & 100 & \\
\hline
\end{tabular}

\section{RESULTS}

\section{Influence of proline on plant growth under excess Mo}

Excess Mo in the MS medium affected seedling growth significantly at 4-day intervals by decreasing the growth rate. Moreover, $10 \mathrm{mM}$ Mo supplemented with Pro also decreased the seedling growth, root and hypocotyl lengths, cotyledon length, and cotyledon width. By adding different concentrations of Pro to excess-Mo media, seedlings could grow out true leaves, where the higher the concentration of Pro, the higher the percentage of leaf growth. Specifically, the treatment of Mo plus $80 \mathrm{mM}$ Pro reached $53.33 \%$ of seedlings with true leaves, whereas in the control MS with or without Pro, all grew normally (Table 2, Figure 1A). Seedlings produced no root hair in the Mo-alone and Mo plus Pro treatments as compared with the control MS with Pro (Figure 1A). 
Table 2. Effect of proline (Pro) on the growth of molybdenum (Mo)-treated cabbage seedlings.

\begin{tabular}{|c|c|c|c|c|c|}
\hline Treatments & Without Pro & Pro $20 \mathrm{mM}$ & Pro $40 \mathrm{mM}$ & Pro $60 \mathrm{mM}$ & Pro $80 \mathrm{mM}$ \\
\hline \multicolumn{6}{|c|}{ Root length $(\mathrm{mm})$} \\
\hline MS & $47.52 \pm 7.86^{\mathrm{b} *}$ & $31.43 \pm 8.66^{\circ *}$ & $54.97 \pm 11.56^{\mathrm{a} *}$ & $50.79 \pm 12.03^{\mathrm{ab} *}$ & $45.54 \pm 14.55^{b *}$ \\
\hline Mo10 mM & $15.23 \pm 2.66^{\mathrm{d}}$ & $13.45 \pm 3.58^{\mathrm{d}}$ & $12.45 \pm 3.12^{\mathrm{d}}$ & $12.44 \pm 2.16^{\mathrm{d}}$ & $13.12 \pm 2.81^{\mathrm{d}}$ \\
\hline \multicolumn{6}{|c|}{ Hypocotyl length (mm) } \\
\hline MS & $23.22 \pm 7.11^{\circ *}$ & $21.21 \pm 8.23^{\mathrm{c} *}$ & $38.26 \pm 4.47^{2 *}$ & $34.29 \pm 6.28^{\mathrm{b} *}$ & $35.42 \pm 6.28^{* \mathrm{ab}}$ \\
\hline Mo10 mM & $9.28 \pm 2.14^{d}$ & $7.86 \pm 1.16^{\mathrm{d}}$ & $8.29 \pm 1.59^{\mathrm{d}}$ & $7.12 \pm 0.8^{\mathrm{d}}$ & $7.83 \pm 1.90^{\mathrm{d}}$ \\
\hline \multicolumn{6}{|c|}{ Cotyledon length (mm) } \\
\hline MS & $11.76 \pm 1.32^{\mathrm{a}}$ & $9.64 \pm 1.50^{\mathrm{b} *}$ & $12.48 \pm 1.61^{\mathrm{a} *}$ & $12.52 \pm 1.32^{2 *} *$ & $12.04 \pm 1.05^{* a}$ \\
\hline Mo10 mM & $9.17 \pm 1.00^{\mathrm{bc}}$ & $8.39 \pm 0.68^{c}$ & $9.49 \pm 1.17^{\mathrm{b}}$ & $8.83 \pm 1.11^{\mathrm{bc}}$ & $9.09 \pm 0.72^{\mathrm{bc}}$ \\
\hline \multicolumn{6}{|c|}{ Cotyledon width $(\mathrm{mm})$} \\
\hline MS & $6.30 \pm 0.74^{b *}$ & $4.97 \pm 0.78^{\text {cde }}$ & $7.10 \pm 0.66^{a *}$ & $7.15 \pm 1.45^{\mathrm{a} *}$ & $5.99 \pm 0.35^{\mathrm{b} *}$ \\
\hline Mo10 mM & $4.72 \pm 0.56^{\mathrm{cd}}$ & $4.49 \pm 0.48^{\text {cde }}$ & $4.52 \pm 0.47^{\text {cde }}$ & $4.25 \pm 0.45^{\mathrm{de}}$ & $4.16 \pm 0.40^{\mathrm{e}}$ \\
\hline
\end{tabular}

Values are reported as means \pm SD. Means followed by the same superscript letter in a row of MS with Pro and Mo with Pro are not significantly different by the LSD test at $\mathrm{P} \leq 0.05(\mathrm{~N}=15)$. *Values between MS and Mo (column) are significantly different by the Student $t$-test analysis at $\mathrm{P}=0.05$ and $\mathrm{N}=15$.
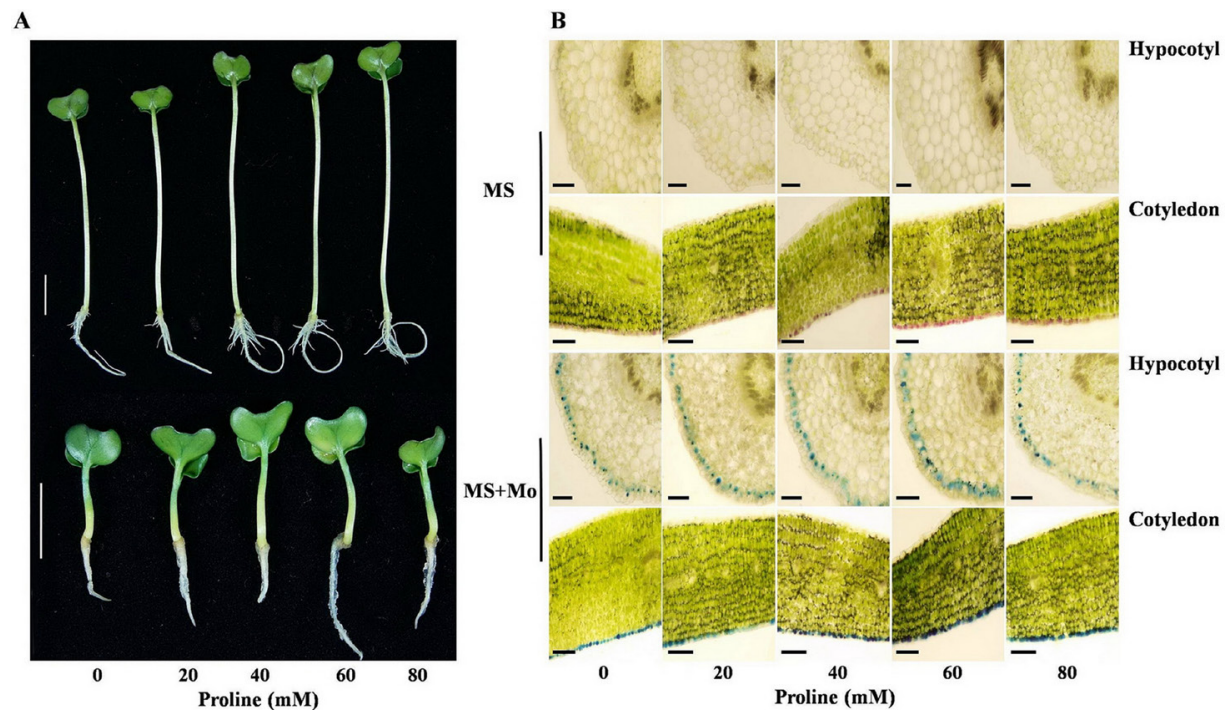

Figure 1. Four-day-old cabbage seedlings grown in vitro on MS with and without molybdenum (Mo). Both were supplemented with proline (Pro) at different concentrations of 0, 20, 40, 60, and $80 \mathrm{mM}$ (row from left to right). A. MS (top) and Mo with Pro treatments (bottom) $(\mathrm{bar}=5 \mathrm{~mm})$. B. Anthocyanin pigment evident in the epidermal cell layer of hypocotyls and cotyledons (bar $=0.1 \mathrm{~mm})$.

\section{Anthocyanin pigment accumulated in the epidermal cells of Mo-treated seedlings}

The hypocotyl sections showed accumulation of the blue pigment in the epidermal cell layer under both the Mo-only and Mo with Pro treatments, whereas no pigment was observed in the hypocotyl epidermis in both the MS-only and MS with Pro treatments during the 4-day experiment (Figure 1B). Blue and purple pigments were also present in the cotyledon cross-sections of Mo-treated seedling no matter if Pro was supplemented or not, whereas control without Mo showed regular pink coloration in cotyledons (Figure 1B). These results suggest that the presence of excess Mo was correlated with the blue pigment formation in cabbage tissues. 
The total anthocyanin content of the cotyledons, ranging from 0.007 to $0.03 \mathrm{mg} / \mathrm{g}$ FW for treatments of Mo with and without Pro, was significantly different from the control MS with and without Pro. The anthocyanin content under excess Mo with $40 \mathrm{mM}$ Pro increased almost 4-folds as compared with the MS with $40 \mathrm{mM}$ Pro treatment (Figure 2A). The pigment solution appeared pink to purple in the Mo with and without Pro treatments, whereas the control was light pink (Figure 2B).

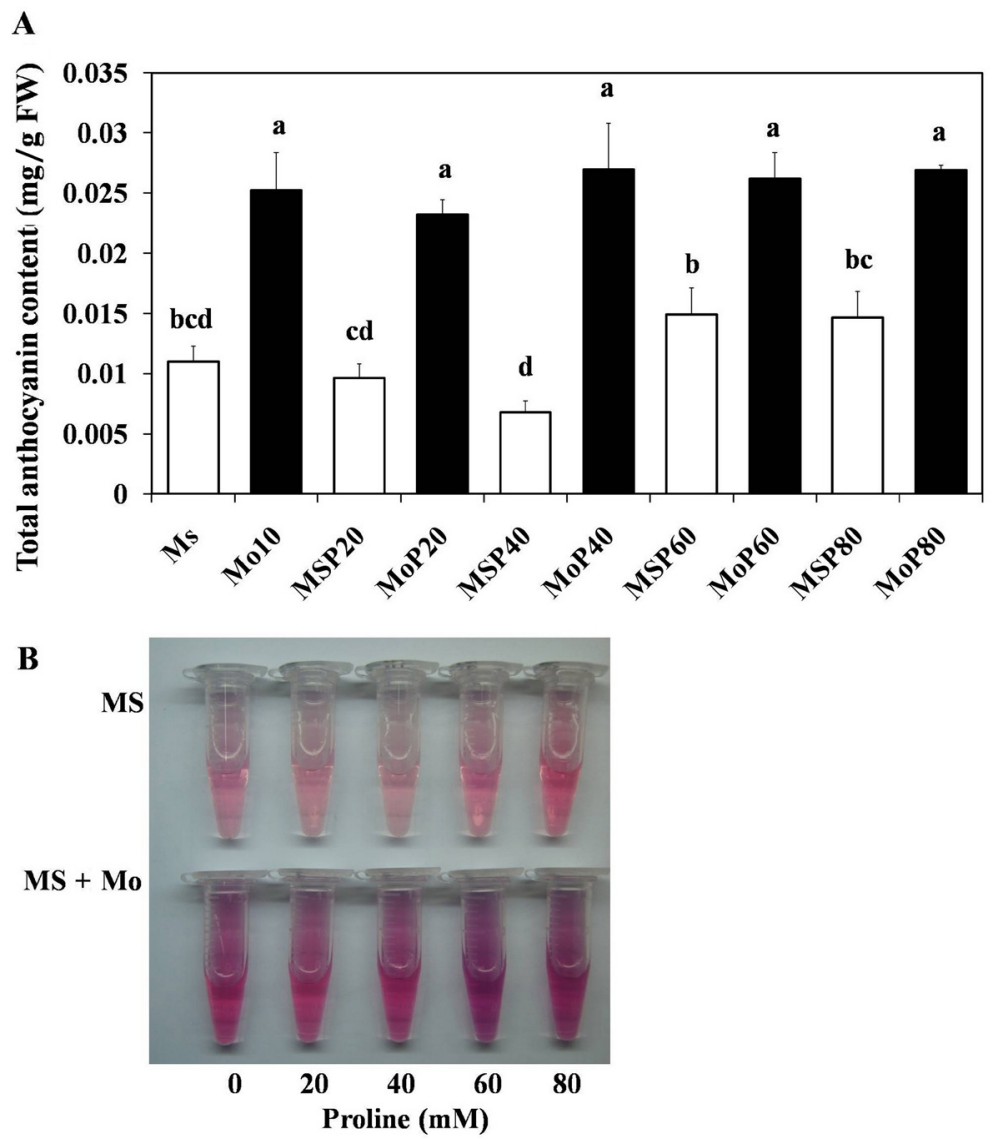

Figure 2. Anthocyanin changes in cabbage seedlings under MS (control) and molybdenum treatments, both supplemented with proline (P) at 0, 20, 40, 60 and $80 \mathrm{mM}$ for 4 days. A. Total anthocyanin content. B. Appearance of anthocyanin extracts from cabbage seedling shoots using $1 \% \mathrm{HCl}$ in methanol. Values are reported as means $\pm \mathrm{SD}$ of three replications. Means followed by the same letter are not significantly different by LSD test, $\mathrm{P} \leq 0.05$ and $\mathrm{N}=3$.

The total $\mathrm{Chl}$ and $\mathrm{Chl} b$ contents were increased (Figure 3A). The Chl $a$ content was higher in MS with $40 \mathrm{mM}$ Pro, and significantly different from Mo treatment at the same Pro level, and also higher than the control MS. The Chl $a$ content in medium with Mo only was not significantly different from Mo plus Pro treatments. Seedlings treated with both Mo and Pro had much higher Chl $b$ than seedlings in MS with Pro (Figure 3A). The seedlings 
and their extracted pigments showed dark green coloration under Mo plus Pro levels (Figure $1 \mathrm{~A}$ and $\mathrm{B})$.
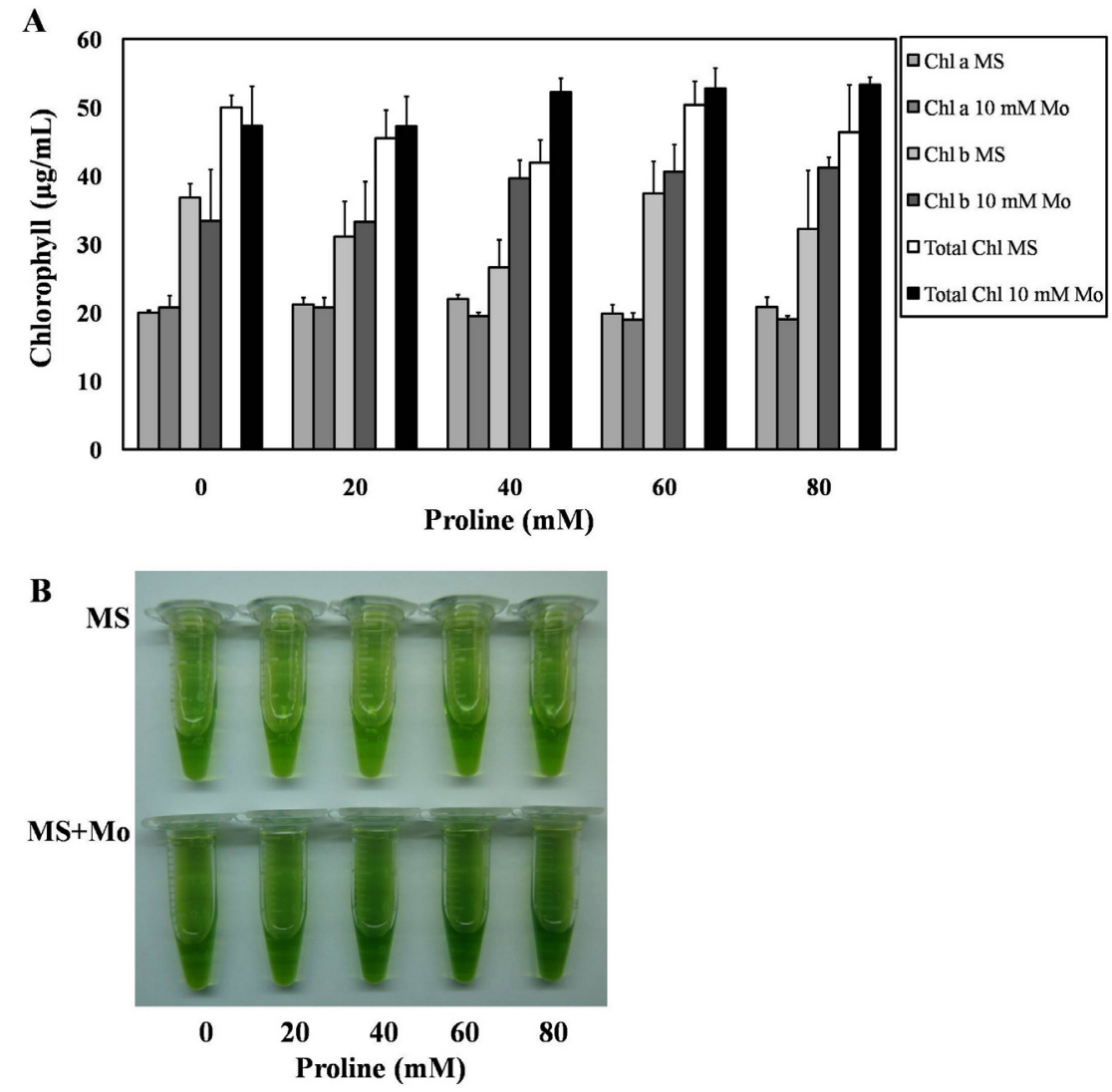

Figure 3. Chlorophyll changes in cabbage seedlings under MS (control) and molybdenum (Mo) treatments, both supplemented with proline at $0,20,40,60$, and $80 \mathrm{mM}$ for 4 days. A. Chlorophyll a and b and total chlorophyll content. B. Appearance of chlorophyll extracts from cabbage seedling shoots using $100 \%$ methanol. Values are reported as means of three replications $\pm \mathrm{SD}$.

\section{Influence of proline on anthocyanin biosynthetic genes of Mo-stressed seedlings}

Since the anthocyanin contents under excess Mo with and without Pro all increased, we examined the expression level of genes in the flavonoid pathway (Figure 4), including $P A L$, $C H S, F 3 H, L D O X$, and GST. These were all upregulated under Mo stress either with or without Pro treatment (Figure 5). High expression levels of PAL (Figure 5A), CHS (Figure 5B), and $F 3 H$ (Figure 5C) were detected in the cotyledon of Mo-stressed seedlings. $L D O X$ was dramatically increased from low to high concentrations of Pro up to $60 \mathrm{mM}$, and then decreased (Figure 5D). GST, the gene responsible for accumulation of anthocyanin in the vacuoles, had a higher transcript level in Mo with $40 \mathrm{mM}$ Pro, followed by that in control medium free of Mo but with Pro (Figure 5E). 


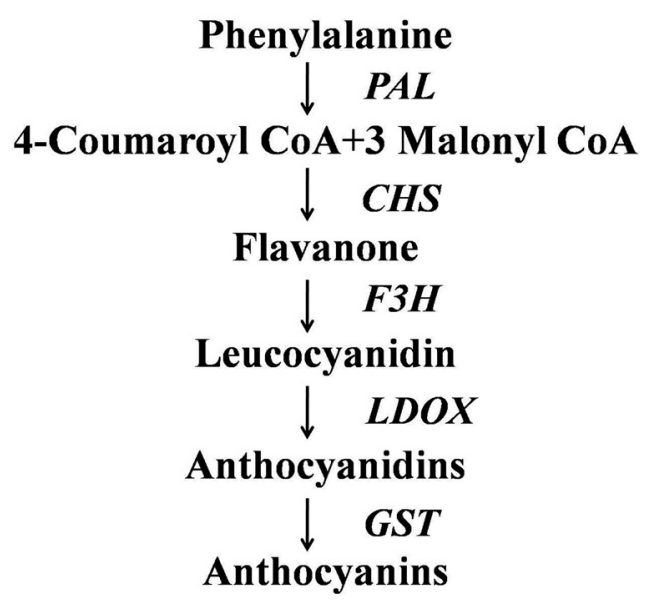

Figure 4. Simplified schematic flow chart of the flavonoid pathway leading to anthocyanins synthesis. The enzymes in this pathway are PAL, CHS, F3H, LDOX, and GST. The pathway was adapted from Petroni and Tonelli (2011).
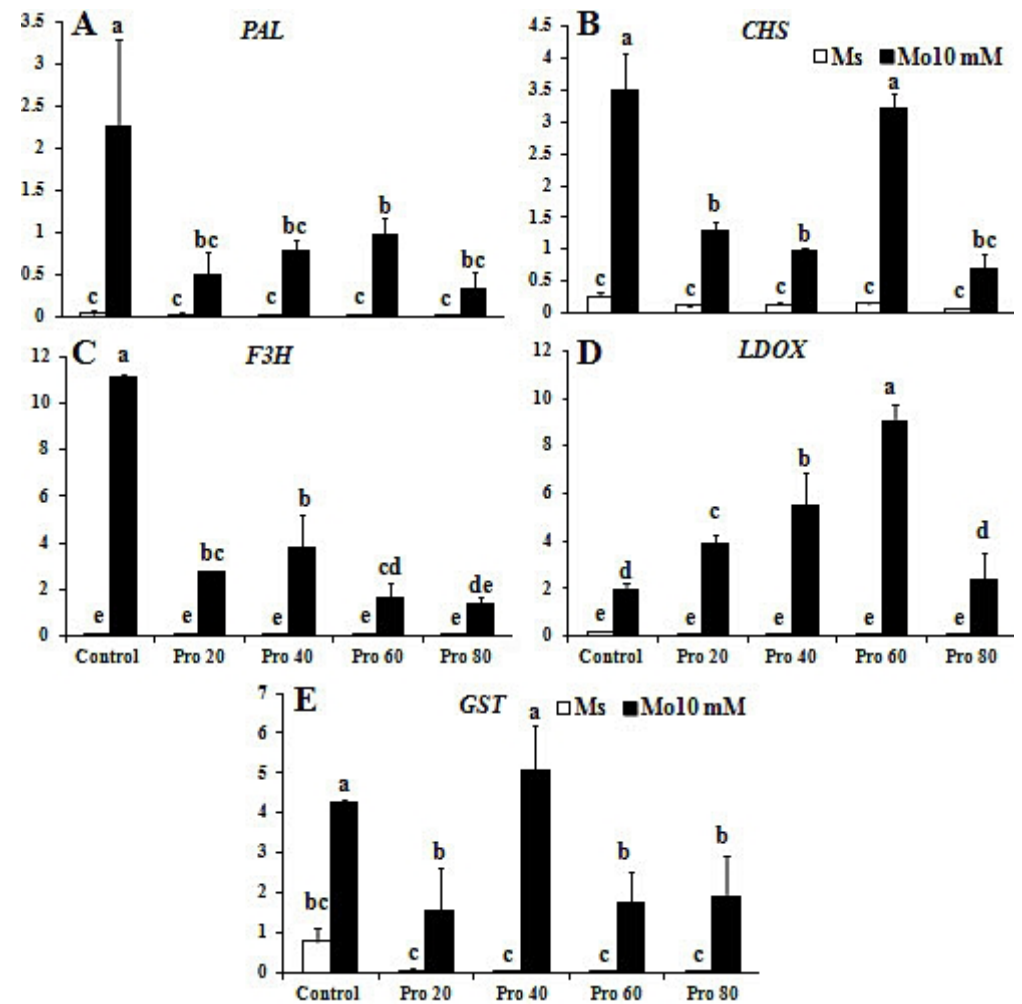

Figure 5. Real-time reverse transcription polymerase chain reaction (RT-PCR) analysis of the expression of anthocyanin structural gene expression: PAL (A), CHS (B), F3H (C), LDOX (D) and GST (E) from cabbage seedling shoots exposed to MS and molybdenum with and without proline at different concentrations, 0, 20, 40, 60, and $80 \mathrm{mM}$ for 4 days. Data are reported as means $\pm \mathrm{SD}$ of three replications. Means followed by the same letter are not significantly different by LSD test at $\mathrm{P} \leq 0.05(\mathrm{~N}=3)$. 
Modulation of antioxidative enzyme activities by proline under excess-Mo condition

In general, the enzyme activities of SOD, APX, and CAT were all increased in seedlings under Mo stress, either with or without Pro (Figure 6). Protein contents were not significantly different between the treatments (Figure 6A). SOD activity was the highest at Mo with both 20 and $40 \mathrm{mM}$ Pro (Figure 6B). APX activity also increased under Mo excess, compared with the control, either with and without Pro, especially at $80 \mathrm{mM}$ Pro. APX activity increased under excess Mo plus 20 to $80 \mathrm{mM}$ Pro (Figure 6C). CAT activity also increase under Mo with $80 \mathrm{mM}$ Pro (Figure 6D).
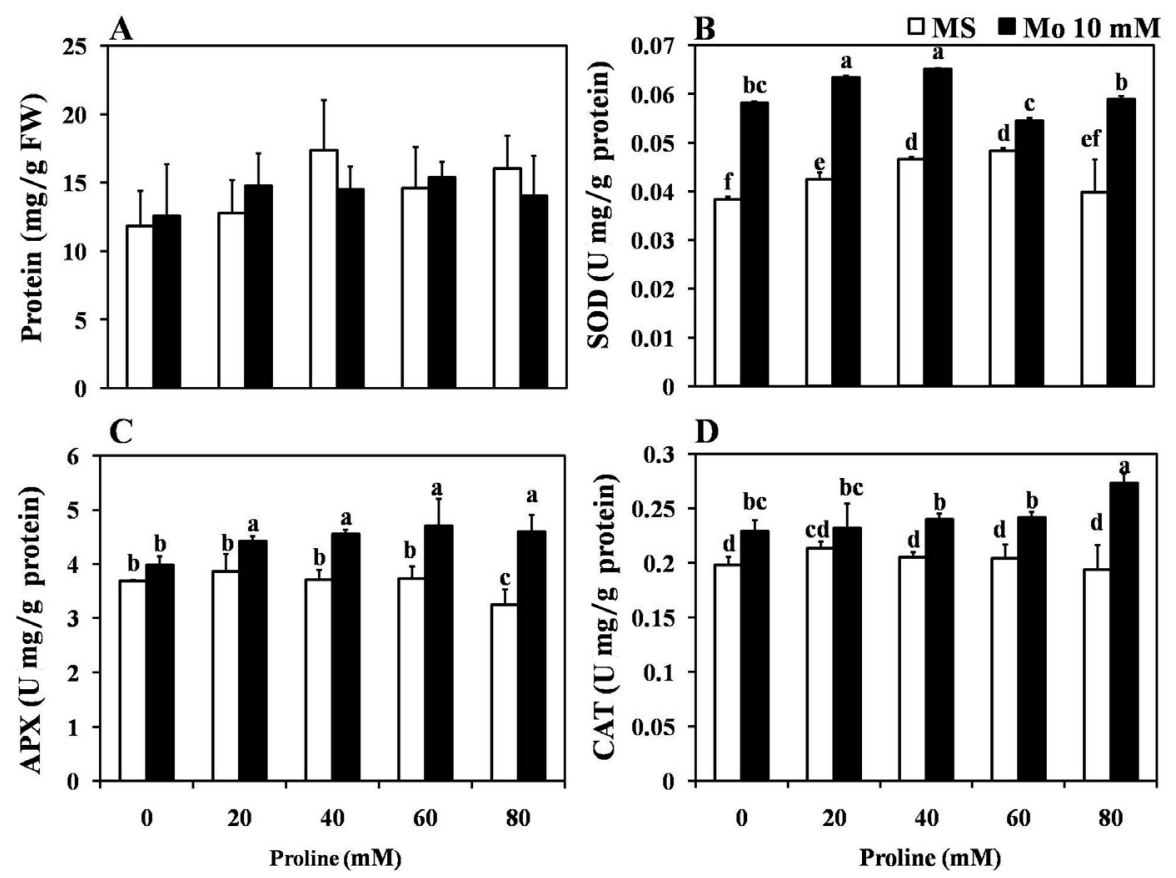

Figure 6. Protein content (A) and the kinetics of the antioxidant enzymes, superoxide dismutase (SOD) (B), ascorbate peroxidase (APX) (C), and catalase (CAT) (D). The activity is presented for cabbage seedlings shoots exposed to MS with proline and $10 \mathrm{mM}$ molybdenum (Mo) with proline at 0, 20, 40, 60 and $80 \mathrm{mM}$ for 4 days. Data are reported as means $\pm \mathrm{SD}$ of three replications. Means followed by the same letter are not significantly different by LSD test $\mathrm{P} \leq 0.05(\mathrm{~N}=3)$.

\section{DISCUSSION}

Mo is an essential micronutrient that is required at a minimum level by plants for metabolism (Kaiser et al., 2005; Mendel, 2005, 2007). As a heavy metal, high concentrations will damage plant cells. McGrath et al. (2010) reported that high Mo concentrations decreased the shoots and yields in tomato, oilseed rape, red clover, and ryegrass. It was shown in our results that Mo reduced/inhibited the hypocotyl length, and shoot and root growth. By the 
addition of Pro to the excess-Mo medium, cabbage seedlings could partially recover their growth, as indicated by the emergence of true leaves, whereas few were observed in the excessMo condition. This result indicates that Pro offered protection together with anthocyanin pigmentation against plant stress conditions such as heavy metals and salinity, as also reported previously (Sharma and Dietz, 2006; Chutipaijit et al., 2011). According to Szabados and Savoure (2009), Pro acts as a signaling molecule and can aid plants in recovering from stress conditions. In the treatment of excess Mo plus Pro, dark green pigment appeared in the seedling extracts, whereas under MS with Pro, the seedlings appeared light green (Figure 3B). The trend of $\mathrm{Chl} b$ accumulation (Figure 3A) also correlated with the excess-Mo condition of dark green color, whereas the control with more $\mathrm{Chl} a$ appeared light green, as also reported previously (Willstätter and Stoll, 1928). High total Chl and the accumulation of $\mathrm{Chl} b$ content might be an effect of Mo (Pirzad et al., 2011). Moreover, Datta et al. (2011) also observed increased levels of Chl $a$ and $b$, total Chl, and sugar under $7.5 \mathrm{ppm}$ Mo in Cicer arietinum.

Under stress conditions such as heavy metals, drought, temperature, etc., plants could be protected by a mechanism that increases its antioxidative properties, such as producing flavonoids, including anthocyanin, and antioxidative enzymes to overcome metal toxicity (Hung et al., 2008; Keilig and Ludwig-Müller, 2009; Sperdouli and Moustakas, 2012). Anthocyanins have been implied to confer tolerance to diverse environmental stressors (Close and Beadle, 2003; Gould, 2004). In addition, plants under salinity stress responded by producing protection agents through an increase of Pro, glutathione $S$-transferase, antioxidant enzymes, and anthocyanin contents (Hoque et al., 2008; Chutipaijit et al., 2011). When Pro was added to MS medium along with a high concentration of Mo, cabbage seedlings produced more anthocyanin than controls in MS with Pro treatments. Enzyme activities of SOD, APX, and CAT were all increased under Mo with Pro. This indicates that exogenous proline could induce antioxidant protection against stress conditions. According to Hoque et al. (2008), exogenous proline mitigates the detrimental effects of salt stress, in its superior ability to increase the activities of antioxidant enzymes, catalase and peroxidase, of tobacco Bright Yellow-2 (BY-2) culture cells in suspension under salt stress. Moreover, proline provides protective action against $\mathrm{NaCl}-$ induced oxidative damage by reducing protein carbonylation, enhancing antioxidant defense and methylglyoxal detoxification systems, and decreasing levels of ROS accumulation and lipid peroxidation, as well as improving membrane integrity (Banu et al., 2009). Khedr et al. (2003) reported that exogenous proline improves salt tolerance by up-regulating stressprotective proteins.

Under Mo excess with and without Pro conditions, there was significant difference in the expressions of the PAL, CHS, F3H, LDOX, and GST genes involved in anthocyanin pigmentation. Mo upregulated early genes of the pathway (PAL, CHS, and $F 3 H$ ), whereas addition of $40 \mathrm{mM}$ Pro to Mo upregulated genes of the last steps, such as LDOX and GST (Figure 5). This upregulation is similar to the results of Qi et al. (2011) in that jasmonate (JA) induced trichome initiation and anthocyanin biosynthesis. The anthocyanin accumulation was increased in the Coil-2 pap 1-D double mutant of Arabidopsis in response to JA treatment. It also upregulated high transcript levels of the anthocyanin biosynthetic genes DFR, LDOX, and $U F 3 G T$. In addition, the genes responsible for flavonoid and anthocyanin syntheses pathways, PAP1, CHS, CHI, F3H, F3'H, FLS, DFR, LDOX, and UF3GT, in Arabidopsis were upregulated by treatment with sucrose, which is the most efficient trigger for mRNA accumulation of the selected genes coding for enzymes involved in the flavonoid biosynthesis pathway (Solfanelli et al., 2006). 
The results of this investigation clearly explained the effect of Pro in alleviation of the growth inhibition imposed in Mo-stressed cabbage seedlings. High Pro concentrations helped recover plant growth under stressed conditions by inducing true leaf growth. In addition, Pro supplemented to the excess-Mo condition increased antioxidant enzyme activity, probably to scavenge ROS, and upregulated anthocyanin genes expression to protect plant cells from the Mo toxicity.

\section{REFERENCES}

Banu NA, Hoque A, Watanabe-Sugimoto M, Matsuoka K, et al. (2009). Proline and glycinebetaine induce antioxidant defense gene expression and suppress cell death in cultured tobacco cells under salt stress. J. Plant Physiol. 166: 146-156.

Baryla A, Laborde C, Montillet JL, Triantaphylides C, et al. (2000). Evaluation of lipid peroxidation as a toxicity bioassay for plants exposed to copper. Environ. Pollut. 109: 131-135.

Bowler C, Montagu MV and Inze D (1992). Superoxide dismutase and stress tolerance. Annu. Rev. Plant Physiol. Mol. Biol. 43: 83-116.

Bradford MM (1976). A rapid and sensitive method for the quantitation of microgram quantities of protein utilizing the principle of protein-dye binding. Anal. Biochem. 72: 248-254.

Chutipaijit S, Cha-um S and Sompornpailin K (2011). High contents of proline and anthocyanin increase protective response to salinity in Oryza sativa L. spp. indica. Aust. J. Crop Sci. 5: 1191-1198.

Close DC and Beadle CL (2003). The ecophysiology of foliar anthocyanin. Bot. Rev. 69: 149-161.

Datta JK, Kundu A, Hossein SD, Banerjee A, et al. (2011). Studies on the impact of micronutrient (Molybdenum) on germination, seedling growth and physiology of bengal gram (Cicer arietinum) under laboratory condition. Asian J. Crop Sci. 3: 55-67.

Dinakar N, Nagajyothi PC, Suresh S, Damodharam T, et al. (2009). Cadmium induced changes on proline, antioxidant enzymes, nitrate and nitrite reductases in Arachis hypogaea L. J. Environ. Biol. 30: 289-294.

Gajewska E and Skłodowska M (2005). Antioxidative responses and proline level in leaves and roots of pea plants subjected to nickel stress. Acta Physiol. Plant. 27: 329-340.

Giusti MM and Wrolstad RE (2001). Anthocyanins: Characterization and Measurement of Anthocyanins by UV-Visible Spectroscopy. In: Hand Book of Food Analytical Chemistry (Wrolstad RE, Acree TE, An H and Decker EA, eds.). John Wiley \& Sons, New York, 19-32.

Gould KS (2004). Nature's swiss army knife: The diverse protective roles of anthocyanins in leaves. J. Biomed. Biotechnol. 2004: 314-320.

Hare PD, Cress WA and Van Staden J (1998). Dissecting the roles of osmolyte accumulation during stress. Plant Cell Environ. 21: 535-553.

Hartmut KL and Buschmann C (2001). Chlorophylls and Carotenoids: Measurement and Characterization by UV-VIS Spectroscopy. In: Hand Book of Food Analytical Chemistry (Wrolstad RE, Acree TE, An H and Decker EA, eds.). John Wiley \& Sons, New York, 171-178.

Hoque MA, Banu MN, Nakamura Y, Shimoishi Y, et al. (2008). Proline and glycinebetaine enhance antioxidant defense and methylglyoxal detoxification systems and reduce $\mathrm{NaCl}$-induced damage in cultured tobacco cells. J. Plant Physiol. 165: 813-824.

Hung KT, Cheng DG, Hsu YT and Kao CH (2008). Abscisic acid-induced hydrogen peroxide is required for anthocyanin accumulation in leaves of rice seedlings. J. Plant Physiol. 165: 1280-1287.

Kaiser BN, Gridley KL, Ngaire BJ, Phillips T, et al. (2005). The role of molybdenum in agricultural plant production. Ann. Bot. 96: 745-754.

Kato M and Shimizu S (1985). Chlorophyll metabolism in higher plants VI. Involvement of peroxidase in chlorophyll degradation. Plant Cell Physiol. 26: 1291-1301.

Keilig K and Ludwig-Müller J (2009). Effect of flavonoids on heavy metal tolerance in Arabidopsis thaliana seedlings. Bot. Stud. 50: 311-318.

Khedr AH, Abbas MA, Wahid AA, Quick WP, et al. (2003). Proline induces the expression of salt-stress-responsive proteins and may improve the adaptation of Pancratium maritimum L. to salt-stress. J. Exp. Bot. 54: 2553-2562.

Masayasu M and Yoshikawa H (1979). A simplified assay method of superoxide dismutase activity for clinical use. Clin. Chim. Acta 92: 337-342. 
McGrath SP, Mico C, Curdy R and Zhao FJ (2010). Predicting molybdenum toxicity to higher plants: influence of soil properties. Environ. Pollut. 158: 3095-3102.

Mendel RR (2005). Molybdenum: biological activity and metabolism. Dalton Trans. 21: 3404-3409.

Mendel RR (2007). Biology of the molybdenum cofactor. J. Exp. Bot. 58: 2289-2296.

Murashige T and Skoog F (1962). A revised medium for rapid growth and bioassays with tobacco tissue cultures. Physiol. Plant. 15: 473-497.

Nakano Y and Asada K (1981). Hydrogen peroxide is scavenged by ascorbate-specific peroxidase in spinach chloroplasts. Plant Cell Physiol. 22: 867-880.

Nazarbeygi E, Yazdi HL, Naseri R and Soleimani R (2011). The effects of different levels of salinity on proline and A-, B- chlorophylls in canola. Am. Eurasian J. Agric. Environ. Sci. 10: 70-74.

Paoletti F, Aldinucci D, Mocali A and Caparrini A (1986). A sensitive spectrophotometric method for the determination of superoxide dismutase activity in tissue extracts. Anal. Biochem. 154: 536-541.

Petroni K and Tonelli C (2011). Recent advances on the regulation of anthocyanin synthesis in reproductive organs. Plant Sci. 181: 219-229.

Pirzad A, Shakiba MR, Zehtab-Salmasi S, Mohammadi SA, et al. (2011). Effect of water stress on leaf relative water content, chlorophyll, proline and soluble carbohydrates in Matricaria chamomilla L. J. Med. Plant Res. 5: 2483-2488.

Posmyk MM, Kontek R and Janas KM (2009). Antioxidant enzymes activity and phenolic compounds content in red cabbage seedlings exposed to copper stress. Ecotoxicol. Environ. Saf. 72: 596-602.

Qi T, Song S, Ren Q, Wu D, et al. (2011). The jasmonate-ZIM-domain proteins interact with the WD-Repeat/bHLH/ MYB complexes to regulate Jasmonate-mediated anthocyanin accumulation and trichome initiation in Arabidopsis thaliana. Plant Cell 23: 1795-1814.

Schützendübel A and Polle A (2002). Plant responses to abiotic stresses: heavy metal-induced oxidative stress and protection by mycorrhization. J. Exp. Bot. 53: 1351-1365.

Sharma SS and Dietz KJ (2006). The significance of amino acids and amino acid-derived molecules in plant responses and adaptation to heavy metal stress. J. Exp. Bot. 57: 711-726.

Smith KS, Balistrieri LS, Smith SM and Severson RC (1997). Distribution and Mobility of Molybdenum in the Terrestrial Environment. In: Molybdenum in Agriculture (Gupta UC, ed.). Cambridge University Press, Cambridge, 23-46.

Solfanelli C, Poggi A, Loreti E, Alpi A, et al. (2006). Sucrose-specific induction of the anthocyanin biosynthetic pathway in Arabidopsis. Plant Physiol. 140: 637-646.

Sperdouli I and Moustakas M (2012). Interaction of proline, sugars, and anthocyanins during photosynthetic acclimation of Arabidopsis thaliana to drought stress. J. Plant Physiol. 169: 577-585.

Stroud JL, Zhao FJ, Buchner P, Shinmachi F, et al. (2010). Impacts of sulphur nutrition on selenium and molybdenum concentrations in wheat grain. J. Cereal Sci. 52: 111-113.

Szabados L and Savoure A (2010). Proline: a multifunctional amino acid. Trends Plant Sci. 15: 89-97.

Tan BS, Lonic A, Morris MB, Rathjen PD, et al. (2011). The amino acid transporter SNAT2 mediates L-proline-induced differentiation of ES cells. Am. J. Physiol. Cell Physiol. 300: C1270-C1279.

Willstätter R and Stoll A (1928). Investigations on Chlorophyll: Methods and Results. The Science Press Printing, Lancaster.

Yuan Y, Chiu LW and Li L (2009). Transcriptional regulation of anthocyanin biosynthesis in red cabbage. Planta 230: 1141-1153. 